\title{
Sustainable Urban Agricultural Land Protection Policy; The Case of Surakarta City, Central Java Province, Indonesia
}

\author{
FX Andy Sutrisno ${ }^{1}$ \\ Research and Development Agency of Surakarta Local Government - Indonesia \\ Bakti Setiawan ${ }^{2}$ \\ Graduate Program of Urban and Regional Planning, Gadjah Mada University - Indonesia
}

\begin{abstract}
This study highlights Indonesia's sustainable agricultural land protection policy, especially the issue of conservation within the urban environment. This study aims to assess the Surakarta Local Government policy for protection of urban agricultural land and to explore the perceptions of urban farmers and agricultural landowners in responding to the policy. This research is expected to bridge the gap between the policy and the interests of farmers and agricultural landowners. This research is based on a case study. Data and information were gathered through field observations, interviews with various stakeholders and secondary data collection. This study found that the policy is not well understood by farmers and landowners, who are the directly affected party. Moreover, the local government actually views urban agricultural land from an economic standpoint and tends to be less supportive of this conservation effort. Instead, farmers and agricultural landowners are the ones who believe that this policy is essential. Nevertheless, they reject the policy because they must relinquish some rights to their land after it has been designated as sustainable urban agricultural land. Another shortcoming is that the promised incentives are not economically sufficient to compensate them for their efforts in protecting the agricultural land. The study recommends progressive policies to reduce the gap between the policy's intentions and the interests of farmers and agricultural landowners, as well as to respond to the obstacles that may arise in the implementation of the policy. It is intended that the purpose of conservation and food security be achieved, without harming the farmers' or agricultural landowners' rights.
\end{abstract}

Keywords: urban, agricultural land, sustainable urban agricultural land, protection.

\footnotetext{
${ }^{1}$ FX Andy Sutrisno is a Head of Data and Documentation Subdivision of Planning, Research and Development Agency of Surakarta Local Government. Email address: fx@ndysutrisno.com

${ }^{2}$ Bakti Setiawan is a Professor and Head of Graduate Program of Urban and Regional Planning, Gadjah Mada University.
} 


\section{Sustainable Urban Agricultural Land Protection Policy; The Case of Surakarta City, Central Java Province, Indonesia}

\section{FX Andy Sutrisno and Bakti Setiawan}

\section{Introduction}

The Indonesian Government has responded to the issue of national food security and the rise of Agricultural Land (AL) conversion by establishing the Spatial Act No.26 of 2007 and the Sustainable Agricultural Land Protection Act No.41 of 2009 (the SALP Act). According to the SALP Act, Sustainable Agricultural Land (SAL) is AL that is protected and developed consistently to produce staple foods that achieve national food independence, security and sovereignty. In Section 48 article (1) of the Spatial Act, it is declared that the spatial planning of rural areas is encouraged to protect AL for sustainable food security. This provision was followed by the enactment of the SALP Act. At first, the Spatial Act only regulated the protection of SAL in rural areas. However, the SALP Act then expanded the protection of SAL in both rural and urban areas.

As the mandate of the Acts mentioned above, the Surakarta Local Government has enacted the Spatial Planning of Surakarta City 2011-2031 Local Regulation No.1 of 2012 (the SPSC Local Regulation). In this local regulation, it has been stipulated that there must be 111 hectares of Sustainable Urban Agricultural Land (SUAL) within Surakarta City.

The researches questions arise of this study are: How well is the SUAL protection implementation in Surakarta City progressing? What are the stakeholders' perceptions to SUAL protection in Surakarta City? And is there a gap between the policy that has been implemented by the government and the perceptions of the stakeholders?

By that, the objectives of this study are: to evaluate the effectiveness of SUAL protection policy in Surakarta City; to understand the perceptions of stakeholders, especially the urban agricultural landowners, in relation to the protection of SUAL; and to provide alternative ways of reducing the gap between policy intention and the needs of urban agricultural landowners.

\section{Literature Review}

The FAO says that one of the potential support mechanisms for food security is urban agriculture, particularly for strengthening urban food security (Redwood, 2009). This is in accordance with the prediction of Smit et al (1996), in Redwood (2009), that 15-20\% of world food would be grown in the city. So, it cannot be denied that urban agriculture is one method to secure food. Besides being a source of global food, urban agriculture becomes important for the city itself. Agyeman (2013) claims that one of the just sustainability factors is food. Agyeman (2013) rewords what Bob Bullard and Bob Evans previously said, that sustainability is not merely a green or environmental concern but, more broadly, it is about how a community is able to meet its social, welfare and economic needs integrated within a limited environment. Based on this understanding, Agyeman (2013) stated that, when a city can meet its welfare needs, including food requirements, then the city could be categorized as sustainable. 
In the future, there will be some problems related to food provision. Firstly, the world's population will increase considerably. The world's population growth, from 6.7 billion in 2007 to 9.2 billion in 2050 (Cribb 2009; Matuschke 2009), has raised the demand for food. Cribb (2009) says that, in the future, the world food demand will be doubled. Secondly, the amount of AL continues to plunge because of land conversion. The FAO states in the last two decades, nearly $15 \%$ of land was converted worldwide and it is predicted that the trend will continue in the future, at a rate of approximately $1 \%$ (or 50,000 square kilometres) per year (Cribb, 2009). Thirdly, the number of farmers has declined. In 2003, there were around 31.17 million farmer households in Indonesia (BPS, 2013). In a ten-year period, the number decreased to 26.13 million farmer households. If this trend continues, farming might become a rare profession in the future. Most people tend to ignore the importance of farmers to their lives (Cribb, 2009). Fourthly, urbanization has considerably increased. Zeeuw, Veenhuizen and Dubbeling (2011) and Cribb (2009) expose the fact that the worldwide urban population will grow from 3.3 billion in 2007 to 6.4 billion in 2050 . They predict that, in $2030,60 \%$ of the world's population will dwell in urban regions.

The current mindset of what constitutes urban and rural challenges the protection of SUAL because the concept of "urban" leads to lack of infrastructure for agriculture. However, there are so many advantages that support the securing of SUAL. The first is that SUAL is unalterable and provides benefits for the environment. People sometimes think that land is just a commodity that gives benefits if sold for a high price (Farm Foundation, 2004). By protecting the existing AL, urban regions show that they have thought about and prepared for the worst future food situation (Cribb, 2009).

The second advantage of SUAL is that it provides a chance for urban farming to grow. Food is an important necessity for cities. To remain a place for urbanization, urban regions should solve their poverty problems, especially food shortages. If this issue is not handled well, that will influence urban stability factors, such as safety and comfort. Providing SUAL for urban farming is one of the solutions, especially for the poorer sections. Urban farming is a medium for urban poor people to survive in a time of crisis (Zeeuw, Veenhuizen and Dubbeling, 2011; Bryld, 2002).

The third benefit is that SUAL can be used as open spaces and for conservation. In urban regions, especially in Indonesia, open space is quite scarce. SUAL can satisfy this open space shortage. Since SUAL can be utilized for conservation, it can provide water buffering capacity and reserved underground water, as well as controlling water flow and flooding, increasing humidity in arid areas and maintaining air quality (Zeeuw, Veenhuizen and Dubbeling, 2011; Xu, 2011; American Farmland Trust, 2003; Bryld, 2002; Land Research and Development of the Agriculture Ministry of Indonesia, 2001).

The fourth advantage of SUAL is that it introduces farming activities to the young urban generation and provides tourism destinations. SUAL areas can be places for education. $\mathrm{Xu}$ (2011) argues that SUAL areas can be tools for science and education.

Growth management measures' stated objectives are, variously, to reduce public sector costs of providing infrastructure and services, promote compact growth, manage traffic levels, preserve farmlands and, in other ways, improve overall quality of life for community residents (Deakin, 1989). Deakin also says that growth management activity is stimulated by citizen perceptions of severe fiscal and environmental concerns, not just by elitist desires for 
self-enrichment and exclusivity. The statement by Deakin (1989) that citizens' perceptions stimulate the growth management activity is actually the basis of this research thesis. Growth management is not only the domain of the government and the elite, but it can be based on the perceptions of the people. A combined commitment from the government, farmers/ landowners and citizens to protect SUAL is needed and is the only way to meet this challenge. Lane (1998), in Nelson et al (2012), emphasizes that implementation methods for the protection of AL require the commitment and political will of the people: citizens, planners, real estate professionals and lawyers. Westphal (2001) concludes, if there is a consensus of all the people, land use planning programs or strategies, though expensive, can be effectively implemented at the local level.

To cover other aspects of the land conversion matter, including consideration of the rights of AL owners, two alternative policies are provided to change the incentives policy and use of zoning as growth management methods. Firstly, Indonesia can apply modern planning techniques for progressive land use: Transfer of Developments Rights (TDRs); and Purchase of Development Rights (PDRs) (Westphal, 2001). Both of these methods are used to shift development rights for the land to another area. TDRs is performed by the developer who buys the development rights from the landowners, while PDRs is carried out using public money and the development rights are lapsed (Nelson et al, 2012). Secondly, there is the development of SUAL as agro-tourism (Zeeuw, Veenhuizen and Dubbeling, 2011). An example of agro-tourism that uses UAL is Denpasar Agricultural Heritage Park, in Bali. This agro-tourism undertaking utilizes AL from $30 \mathrm{AL}$ owners, and has created tourist attractions such as agricultural activities, fishing, performing arts, dining, and so forth. Hsu (2005), in Budiasa and Ambarwati (2013), gives an example of agro-tourism in Taiwan that can bring in 8.2 million visitors, with total revenue of US\$ 134 million.

\section{Research Methodology}

Predominantly, the qualitative approach is utilized. However, in order to complement the qualitative method, this study also uses quantitative data. This research aimed to obtain comprehensive information associated with the understanding of the SUAL protection policy in Surakarta City. The objects of this study are predominantly from the districts of Banjarsari and Jebres. In this study, the sample for the questionnaire section was 30 people, consisting of 10 farm workers, 10 agricultural landowners and 10 agricultural landowners who also were farmers.

The resource persons for the in-depth interviews representing the policy executors were selected based on the judgment technique, as stated by Nasution (2001), where the speaker is taken from the party that is directly involved in formulating and implementing a policy. In this situation, the judgment technique required selection of the resource persons who were directly involved in formulating and implementing the SUAL protection policy in Surakarta City and persons representing the society. Thus the sample numbers were 30 for the questionnaire and 22 for the in-depth interview.

The analysis was conducted using the descriptive method, which explains the findings from both the interviews and questionnaires, related to the perceptions of the agricultural landowners, farmers, related government agencies and the society leaders of Surakarta City. 


\section{Research Findings and Analysis}

\subsection{Food Security}

One of the objectives of the SAL protection policy, which is inserted in Section 3 Letter (c) of the SALP Act, is to achieve national food independence, security and sovereignty. SAL protection is regulated to facilitate production of food on existing AL in order to achieve food security. This legal, formal definition implies that agricultural activities in Indonesia should be able to provide adequate food for every household, in terms of both quantity and quality, with security, by fair distribution and at an affordable price.

However, unfortunately, the farmers, who are the spearheads of those efforts, have not understood the meaning of food security. The 12 farmers and SUAL owners who became the speakers of this study could not provide a definite meaning of food security. This condition is very ironic, considering that the farmers are the most important part of the SAL protection policy. They are the party that will play the most significant role in achieving food security. The farmers are also the ones who are impacted by the policy, because their AL is the object of the protection policy. From this evidence, it appears that good communication is absent from the government, as policy maker, to its citizens.

If farmers understood the importance of their position in food provision for the public, the understanding would influence their farming activities in a positive way. Regrettably, this basic information is not properly conveyed to the farmers. So, if farmers cannot implement the policy for achieving national food security, they can hardly be blamed. Interestingly, the government agency representatives very clearly understood the definition of food security, even those who were not, institutionally, linked directly to the duties and functions of agriculture. Some members of society also understand the concept of food security, which is better than the farmers.

The responses from farmers, government agencies and the community show an information disparity in the understanding of the concept of food security. Some people might assume that the farmers' ignorance regarding food security is trivial but, actually, this gap in their information and knowledge could be an indirect indication of the relationships among government and society with farmers. It can be presumed that the lack of communication is on the part of the government and society to the farmers, even though the position of farmers is vital for the community. Without farmers, there is no food available to be eaten by the community. This bad communication pattern can be an obstacle to the implementation of government policy, especially in the agriculture sector, for example, in terms of SUAL.

\subsection{Staple Food}

Most Indonesian people consume rice, although, in some areas, people do not put rice as their staple food. For example, in Papua, people mainly eat sago. The Javanese people sometimes say that they feel like they have not eaten until they eat rice, even though they have previously eaten bread or potatoes. Most of the farmers replied that the staple food of the Indonesian people is rice. The government agency and community representatives also corroborated this. However, some people affirmed that other staple food commodities could be developed is potatoes, corn, cassava and sago. The understanding of the Indonesian staple food is closely related to the provision of land that is used to produce the food. If rice is the staple food that is not replaceable, it means that this country needs more AL to grow 
rice. This condition has consequences, because $\mathrm{AL}$ for rice demands special requirements, such as particular slope, water supply and others. The requirements are different if the staple foods are cassava, potato or corn. Those foods do not require such a complex use of AL. This dependence on rice confirms the importance of AL to Indonesia.

According to Sutomo (2004), in Abdurachman, Wahyunto and Shofiyati (2005), in the period of August 1999 - August 2002, the area of AL in Indonesia declined to only 563,159 hectares, of which $30 \%$ was fertile AL in Java Island. This situation indicates that AL, which is important for the provision of food, is in a vulnerable position due to the conversion of land for non-agricultural purposes. Amid the needs for the large areas of AL, the protection of AL becomes quite vital. This includes the protection of UAL. Especially, there is a greater challenge to protect UAL than rural AL, because UAL tends to be more expensive. AL is an irreplaceable resource. Once it is converted, there is no possibility to recover it to be used as AL again.

\subsection{Threats to Food Security}

In the process of achieving food security, there are some threats that must be faced by Indonesia. From the interviews with farmers and UAL owners, the following are the threats that could be disadvantageous factors:

1. Water shortages, as some AL are only rain-fed;

2. Shortage of land, as more land is covered with buildings and concrete;

3. Lack of comprehensive management, for example, poor irrigation supervision, with buildings covering drainage, garbage in the drainage, and other problems.

The first threat is the lack of water. The location of AL within an urban area poses some difficulties for agricultural activities in relation to irrigation infrastructure. Basically, agriculture requires good access to water. Due to the difficulty of obtaining water, AL in Surakarta is rain-fed, so the AL can only be used for growing rice when the rainy season comes. Consequently, the rice planting time is limited and that affects the amount of food produced.

The second problem is the shortage of land. Farmers and AL owners can see that there is a shortage of AL to grow rice. This has arisen because much AL has been converted. As stated by one of the speakers: "AL is planted with concrete and buildings." What has been said is quite logical. Namely, when the area of AL available to provide food declines, of course, there is a decrease in the amount of food that can be produced. Irawan (2004), in Abdurachman, Wahyunto and Shofiyati (2005), explains because of the AL conversion in Java Island during the period of 1978-1998, which was a loss of 8,000 hectares/year, the rice production was reduced by 4.70 million ton/year.

The condition will become worse if the allocation of new AL does not follow this decline of AL. It is necessary for the government to seriously consider the conversion of AL because it will have an impact on the achievement of food security in Indonesia.

The third threat is the lack of a comprehensive management system in agriculture. Some farmers think that the absence of integrated development and the lack of coordination among many sectors are serious problems for urban agricultural activities. As stated by one informant: "The gutters become clogged, because many buildings cover the drain. It makes the irrigation become blocked." 
In general, the government agencies and society see that the threat to food security is the decline in area of AL caused by AL conversion. There is a suggestion to increase the added value for urban agricultural activities, considering that traditional agriculture can only fulfill the farmers' needs. With the added value, it is expected that land conversion would not occur. The other threat is the weakness of regulations related to AL protection.

\subsection{The SUAL Protection Policy in Surakarta City}

The government is the most responsible party in the effort to achieve food security. In dealing with the increasing conversion of $\mathrm{AL}$, it has already enacted some related regulations. The enactment of the SALP Act is one of the political and legal breakthroughs from the government for the protection of AL. By the determination of the Act, the government has demonstrated the seriousness of its concerns about AL conversion as well as the achievement of food security.

Farmers and AL owners have some views about the policies that have been issued by the government in relation to AL conversion. The first common view is that they assume the government has not issued policies to protect AL. Although, theoretically, when a legislative product has been enacted, there is a provision that everyone is supposed to know about the regulation, in practice, there is an information gap.

There are two possibilities contributing to this problem. Firstly, farmers lack information on the policy. Even though the policy is closely related to their work, they do not make efforts to find out about the policy. Secondly, there is not enough regulation socialization from the government to the farmers that is quite important. When a policy that has been made can be understood by the society, and it has gained support from that society, then it can achieve its objectives. The second common view is that the farmers consider the government has issued policies to anticipate AL conversions. Nevertheless, having issued this kind of policy, it is believed to be inadequate. Unfortunately, the respondent could not express which part of the policy is insufficient.

The third view is that the government has issued a relevant policy but it is weak in its implementation. More clearly, one speaker says: "Actually, there are policies, but they cannot be realized. That is only in meetings. For example, they said there would be support for fertilizers, seed - but those are actually nothing, or just a little. It is not enough. There are coaching and training programs, but those are not continuous. That is just for a project. There is no control." This view confirms that the policy and regulations are adequate but there are weaknesses at the implementation level. The worst assumption is that the policy is only a formality because, in fact, the implementation does not match with the objectives and there is no control. This is unfortunate, given that, if the policy and regulations were really good and were supported by the appropriate implementation, control and monitoring, actually, this would benefit farmers, government and society. In this case, if the protection of SUAL, which has been regulated at the SPSC Local Regulation, could be implemented by the government and supported by the farmers and UAL owners, SUAL protection could achieve its objective and provide benefits for food provision in Surakarta City. The majority of respondents, $90 \%$, claimed that SUAL protection is very important, with $43.3 \%$ of respondents agreeing and $46.7 \%$ of respondents strongly agreeing. This suggests that, for most respondents, the idea of $\mathrm{AL}$ in urban areas is not a big problem. The respondents think that it is an appropriate policy. 
However, it is also noted that $6.6 \%$ of the respondents think that the policy is not important. A speaker confirms this: "In Solo, the land is very limited. If I have many children, then I would buy houses for them in the agricultural land. I think it is not appropriate to protect agricultural land in this city."

Bappeda (Board of Planning and Development of Surakarta City) actually sees SUAL protection is not really important, because the government of Indonesia has opened AL outside of Java Island. DTRK (Spatial Department of Surakarta City) confirms that the achievement of food security does not always mean it needs to be cultivated in Surakarta. There are other things that could be done. The opening of AL on islands other than Java Island as an alternative is clearly denied by Simatupang and Irawan (2003) who state that the development of new AL outside Java has improved AL in quantity, but not in quality. This is due to the biophysical conditions of AL outside Java Island being lower than the biophysical conditions of AL on Java Island. It is proved by the fact that the additional food production from AL outside Java Island has not significantly increased national food production. Java Island is still the major national food supplier by 55\%. Pasandaran (1998), in Abdurachman, Wahyunto and Shofiyati (2005), claimed that the productivity of AL outside Java Island is only 1.5-3 tons/hectare. Therefore, in replacing the loss of one hectare of AL in Java Island, 4-5 hectares of new irrigated AL outside of Java Island should be created.

Even though SUAL protection is considered to be an appropriate policy, some farmers describe that there will be some challenges for SUAL protection policy implementation, which are the shared inheritance within a farmer family, irrigation and an external factor: the competition with developers who want to use UAL as settlements, as part of their business. However, they say that the policy provides advantages for farmers. It is based on the consideration that the protection of SUAL in Surakarta City will guarantee their source of lifetime income. By the protection of SUAL, that SUAL will still exist and the farmers' workers will have the opportunity to work there. Some speakers stated that their skills are just in the agricultural area. So, agricultural activities in Surakarta City are their focus of attention. To protect the SUAL in Surakarta City means to protect the farmers' lifestyle. The government agency and society representatives also thought that the SUAL protection policy provides benefits for farmers, in Surakarta, especially, and to the Surakarta people, generally.

\subsection{Perceptions of SUAL in Surakarta City}

The AL productivity and the rice needs of Surakarta City depicts that, actually, this city has no capability to meet its rice needs. The rice production of Surakarta is not too considerable, regarding that it does not satisfy even $1 \%$ of the total needs. This fact is actually understood by farmers and AL owners. One speaker says that the production is just a little help. It means that SUAL protection can help the government to achieve food security, but it cannot be significant. However, the majority of informants believe that the policy objectives could facilitate attainment of food security. When, economically, the AL is not worth being processed because of the small area of land, physical limitations, high operational costs including expensive land taxes, and the policy prohibiting AL owners from selling their AL, literally, the policy burdens the AL owner. Among the dominant responses that expressed disapproval about the prohibition on selling or changing the purpose of AL, there are still AL owners who were resigned to the condition by saying, "So, I will find another job." That 
means, the AL owner will keep the AL but, to meet his economic needs, the AL owner will support his family by taking another job.

Indeed, SUAL protection, which prohibits AL conversion and the selling of land that would change its purpose, tends to harm the AL owners' interests. Therefore, the SUAL protection policy should be reviewed, including its relationship with the Basic Agrarian Act that respects private land rights. As property rights recognized by law, the AL owners should have the freedom of authority on their land. Below are the responses of the respondents on their intention to protect AL. The majority of respondents (83.3\%), being 70\% who agree and $13.3 \%$ who strongly agree, are eager to protect their AL. There were $10 \%$ of respondents who were neutral, while the remaining were $3.30 \%$ who disagreed and $3.30 \%$ who strongly disagreed. The responses confirm that almost all farmers have a strong relationship with their land. Therefore, they do not want to sell their AL. This is in accordance with what was found by Jamal (1999) in Simatupang and Irawan (2003); that most of the farmers who sell their land, basically, do not want to sell the land. Related to the intention to sell AL or protect it, one speaker said that he has the intention to never sell his AL because it is the source of his income. Another informant explained that the reason why he does not want to sell his AL is because it is an inheritance from his parents.

Basically, the AL is the source of income and lifestyle. However, when the AL is passed to the children, the rights become the children's as to whether or not they want to sell it. Witjaksono (1996), in Simatupang and Irawan (2003), describes that the sale of AL by farmers is not socially beneficial, because AL ownership is a social symbol.

So, it is not surprising that the majority of AL owners want to protect their UAL. Although, when they have to face the financial needs of inheritance issues, for example, the principle could change. Some people assume that urban areas are not the places for agricultural activities. Agricultural activities have a place within rural areas. This is because agriculture in rural areas will have more flexibility, with the vast area, sources of water and other benefits. Contrarily, urban agriculture will have obstacles, such as poor water resources, high price of agricultural land, and so forth.

Following are the obstacles for farmers to undertake agricultural activities in the city: High production costs, such as fertilizer prices and labor costs; Less irrigation, in some places depending on rain; Limited number of farming workers; Pests; Unavailability of fertilizers; and also lack of government attention. However, the informants considered that water is one of the main obstacles in the implementation of agricultural activities in Surakarta. Moreover, the water problem is worsening due to the clogged irrigation channels because of garbage and to the development of settlements along the irrigation channels. The production costs in the city also are relatively high. In particular, farmer workers are really expensive. Respondents also thought that the government gives less attention to urban agricultural activities.

\subsection{Perceptions on Government Support for Agricultural Activities in Surakarta}

Economically, UAL in the city remains as a life support for AL owners and farmers, to gain money or, at least, rice. UAL is also considered to be one of to the components for achieving food security. Though the food production is not too significant, the result is still important. Informants also described how UAL, ecologically, makes the air fresh and greens the environment. Farmers, as an important part of the food production system in 
Indonesia, actually need special attention from the government. The implementation of SUAL protection, as regulated in the SALP Act and The Incentives of Sustainable Agricultural Land Protection Government Regulation No.12 of 2012, has prescribed incentives for AL owners whose land is designated as SAL or SUAL such as dispensation or reduction of land tax; development of agricultural infrastructure; financing for excellent seeds and varieties research and development; ease of access to information and technology; provision of agricultural production tools; financial aid for the issuance of SAL rights certificates; and/or awards for farmers' achievements.

The incentives above are the types of support available from the government to the farmers related to the implementation of the SALP Act. Below is the response of AL owners and farmers to the government's support for urban agricultural activities before the enactment of the SALP. From respondents, 50\% of the respondents (of which $13.3 \%$ strongly disagreed and $36.7 \%$ disagreed) did not agree that the government had supported their agricultural activities. Neutral responses were given by $10 \%$ of respondents, while $40 \%$ of respondents agreed that the government had provided support to urban agricultural activities, by $6.7 \%$ agreeing and $33.3 \%$ strongly agreeing.

The composition of these responses could describe indirectly that government support for urban agricultural activities was not spread evenly, due to the fact that $50 \%$ of respondents did not agree that the government had supported them. From the conducted interviews, there was a very noticeable difference in the level of government support. Firstly, the speakers who were in the District of Jebres claimed that they did not get any help from the government, while informants who were in the District of Banjarsari actually did receive support. Secondly, the receivers of the support were only farmers' collectives, such as groups of farmers in Banjarsari District, while individual farmers in Jebres District did not get government support.

Apparently, despite it being said that the previous government support was not maximal, more than half of the respondents remained optimistic that the incentive policy would run well, with $56.7 \%$ of respondents agreeing, $20 \%$ of respondents being neutral and $23.30 \%$ of respondents disagreeing. The dominant positive responses illustrate that respondents have a big hope that the government will provide better support for them and act more consistently in controlling the incentives such as: "Insha Allah, if the agricultural land is protected, then the irrigation is repaired, the government gives the assistance, and I believe that we can produce better."

However, there were also respondents who doubted the commitment of the government, due to their previous experiences where the government could not provide them with maximum support. Those respondents felt pessimism about the consistency of the government in the future.

\subsection{Discussion}

1. Rice production in Surakarta City, (with productivity of 5.6 tons/hectare, a total of 111 acres of AL, and the rice needs of 500,171 inhabitants), is only capable of supporting $0.88 \%$ of the Surakarta City population. This means that the agricultural production in this city is not too significant.

2. The farmers' predominant income level, from the survey, is below Rp. 2,000,000. It might 
be sufficient for their daily life, but it would not provide prosperity for them. In this modest situation, the farmers are shadowed by the lure of selling their land, which is more lucrative. Based on the market price of land, the price of land for housing purposes is quite high. In the market, AL for settlement could be sold for three times its land tax value.

3. As a top down policy, the Local Government of Surakarta actually does not agree with the obligation to determine SUAL in this city, as expressed by Bappeda and DTRK. Bappeda has requested the government in Central Java Province to make changes to the SPSC Local Regulations. The technical government agencies can only implement the existing rules and wait for the new rules.

4. Farmers and AL owners do not understand the concept of food security. In my opinion, the ignorance of farmers about the concept of food security is not a trivial thing. There are information and knowledge gaps that can indirectly show the pattern of non-communication between the government and society with farmers. The bad communication between farmers and the government could be an obstacle for the implementation of government policy, especially in the agricultural policy areas, because the farmers are spearheading the achievement of food security.

5. The challenges of urban agriculture are: lack of water, lack of land (competing with the settlement developers), and uncoordinated agriculture management systems (such as developments in other places that damage irrigation).

6. About $90 \%$ of the farmers and AL owners in this study agreed that the protection of UAL is really important. However, when the AL owners know that they cannot sell their AL or change its purpose, they definitely object to this policy. Conceptually, they agree to the protection of SUAL, but they still want to have freedom of authority over their own land. So, when they need money or want to divide their inheritance, they want to be able to sell the AL or change its purpose. The government agencies also consider that the protection of SUAL is important but it is not realistic. The society also corroborates that these efforts will be in vain. However, if this protection of SUAL continues, the UAL will not be considered as a place of production, but it could be green open spaces.

7. The majority of AL owners claim that the incentives offered by the government would not be comparable to them selling their AL. They have learned, from experience, that the government support is not maximal. If the government then promises other incentives, they are doubtful that the program would be run well.

8. In terms of sustainability, the protection of SUAL should not be emphasized just in economic terms. It is important to calculate the value of social and environmental benefits too. Based on the economic principles, for government and society, the protection of SUAL will cost too much. The government should fix or develop irrigation, provide the incentives, and so on, while the outcomes are not worth the expense. The condition is also the same for the AL owners and farmers, where agricultural activities actually do not benefit them economically and the UAL has a high value if they sell it. In the economic aspects of sustainability, it is considered that UAL will provide benefit if the AL is used for non-agricultural purposes. However, actually, UAL has many advantages for the city. In environmental terms, UAL has a function to reserve underground water, maintain air quality, increase the area humidity, provide green spaces, and more. One 
thing is certain; UAL is an irreplaceable resource. If it is lost, it will never come back. So, the environmental aspects will influence the social aspects too. Regarding that the agricultural production in Surakarta City could provide food for $0.89 \%$ of the Surakarta population and as work for around 1,200 farmers in Surakarta, if the protection of SUAL fails, that will create new social problem for Surakarta, including unemployment for the farmers and lack of food for people who depend on the UAL.

9. The protection of SUAL is a valid and important policy. This policy will support food provision in the future. A solid commitment from the government and all of the citizens will be a great asset towards implementation of SUAL protection. However, the government still should improve the policy in order to reduce the disparity between the incentives given by government and the responsibilities taken on by AL owners to protect their land. This is the gap that occurs, where the government regulates the AL owners to protect their AL with incentives, and also punishments for violations, while the AL owner does not agree because the incentives are not balanced, agriculture is not profitable, and they feel they have rights over the AL. To minimize this gap, the government should find a win-win solution. The government could implement TDRs and PDRs. By implementing TDRs and PDRs, the money that should be spent is not as much as the money required buying the entire AL outright. If the regulations can cover these methods, TDRs and PDRs could be implemented to minimize the gaps in SUAL policy. Additionally, as another solution, the Local Government of Surakarta can attempt an innovation by using UAL for urban agro-tourism purposes. Urban agro-tourism can improve the farmers' revenue and provide direct benefits for the society itself.

\section{Conclusions and Recommendations}

\subsection{Conclusions}

The research has provided answers that can be summed up as follows:

1. The SUAL protection policy is effective; regarding that there is no more land conversion since that the government agencies related to business-licensing implement the local regulation by not issuing any permits for conversion of AL in Surakarta City.

2. The stakeholders' perceptions of the SUAL protection policy are as follows:

a. The government agencies of Surakarta City consider that the protection of AL in this city is important. However, the agencies see many obstacles in the implementation of the policy and think that, actually, agriculture has no place in the city. Thus, the agencies have proposed changes to the SPSC Local Regulations, by requesting that the Central Java Province will no longer require Surakarta City agencies to determinate SUAL.

b. The community believes that the protection of SUAL is vital. Nevertheless, its protection will be useless and difficult to implement while there are problems such as lack of irrigation infrastructure. SUAL might be protected, but not for the proponents of food security. The SUAL will be more functional as open space. 
c. Farmers and AL owners deem that SUAL protection is essential. It is very significant for the farmer workers/peasants because protecting SUAL means protecting their jobs. However, AL owners consider the prohibition on selling AL or changing its purpose is not fair. The incentives are also regarded as unfair because they are not in balance with the obligations to protect AL. Farmers and AL owners agree with SUAL protection, but they have to have free authority over their AL, including whether they want to sell it.

3. The gap occurs because, on one side, the government intends to set aside SUAL in Surakarta City by giving incentives, while, on the other side, AL owners and farmers consider that the given incentives are no compensation for the obligation to protect SUAL. Policy cannot satisfy every party, but the government should take action to reduce the gap. The goal of this effort would be that the aim of SUAL protection could be achieved while the farmers' and AL owners' interests would not be harmed.

4. Some tools have been suggested to reduce the policy gap. The first is the implementation of progressive methods of land use planning techniques, which are TDRs and PDRs. The second is the implementation of a creative economy by the creation of urban agrotourism in Surakarta City.

\subsection{Recommendations}

Finally, here are some recommendations:

a. The government should improve its communication with the farmers using any approach that could be received by them, considering that farmers are the important elements in achievement of food security.

b In the implementation of any program to support agricultural activities, the government should accompany the process with strict supervision. This is for achieving the objectives of the program and for the farmers' and societies' benefit.

c. Considering that SUAL protection is deemed to be essential by all of the stakeholders, the government should take action to reduce the gap, in order to make SUAL protection programs run well. The actions that could be taken are the implementation of TDRs and PDRs, and also the development of urban agro-tourism in Surakarta City, as has been done in Denpasar City, Bali Province.

\section{References}

Abdurachman, A., Wahyunto, dan Shofiyati, R. 2005. "Kriteria Biofisik Dalam Penetapan Lahan Sawah Abadi di Pulau Jawa." Jurnal Litbang Pertanian, 24(4):131-136.

Agyeman, Julian. 2013. Introducing Just Sustainabilities, Policy, Planning and Practice. Zed Books Ltd. London. New York.

American Farmland Trust. 2003. Why Save Farmland? http://www.farmlandinfo.org/documents/29493/Why_Save_Farmland_Color.pdf.

Bryld, Erik. 2002. "Potentials, Problems, and Policy Implications for Urban Agriculture in Developing Countries.” Agriculture and Human Values, 20:79-86.

Budiasa, I W., \& I G.A. Ambarwati, I G.A.A. 2013. “Community based agro-tourism as an innovative integrated farming system development model towards sustainable agriculture and tourism in Bali." J.ISSAAS, 20 No. $1: 29-40$. 
BPS (Central Bureau of Statistics of Indonesia). 2013. http://www.bps.go.id.

Cribb, Julian. 2009. The Coming Famine, The Global Food Crisis and What We Can Do to Avoid It. University of California Press. Berkeley. LosAngeles. London.

Deakin, Elizabeth. 1989. 'Growth Controls and Growth Management: A Summary and Review of Empirical Research', in Understanding Growth Management: Critical Issues and A Research Agenda, edited by David J. Brower, David R. Godschalk, Douglas R. Porter. The Urban Land Institute. Washington D.C. pp. 3-21.

Farm Foundation, 2004, Farmland Preservation, http://www.farmfoundation.org/news/articlefiles/105April2004FarmlandPreservation.pdf.

Land Research and Development of Ministry Agriculture of Indonesia, Indonesia 2001, Ringkasan Eksekutif, http://balittanah.litbang.deptan.go.id/dokumentasi/prosiding/ mflp2001/ringkaran_eksekutif.pdf.

Matuschke, Ira. 2009. "Rapid Urbanization and Food Security: Using Food Density Maps to Identify Future Security Hotspots.” International Association of Agricultural Economists Conference.

Nasution, M.A. 2001. Metode Research. Bumi Aksara. Jakarta.

Nelson, Arthur C., Rick Pruetz, Doug Woodruff, James C. Nicholas, Julian C. Jergensmeyer, and Jonathan Witten. 2012. The TDR Handbook; Designing and Implementing Transfer of Development Rights Programs. Island Press. Washington. Covelo. London.

Redwood, Mark (ed.). 2009. Agriculture in Urban Planning, Generating Livelihoods and Food Security, Earthscan, VA, USA.

Simatupang, Pantjar dan Irawan, Bambang. 2003. 'Pengendalian Konversi Lahan Pertanian:Tinjauan Ulang Kebijakan Lahan Pertanian Abadi' dalam Proseding Seminar Nasional Multifungsi dan Konversi Lahan Pertanian, Bogor 2 Oktober dan Jakarta 25 Oktober 2002. ISBN 979-9474-20-5:67-83.

Westphal, Joanne M. 2001. "Managing agricultural resources at the urban-rural interface: a case study of the Old Mission Peninsula." Landscape and Urban Planning 57:13-24.

Xu, Lan. 2011. "Economic Assessment of the Non-Market Value of Agricultural Land: A Case Study in Nanjing, P.R. China." Master thesis, Ghent University, http://lib.ugent.be/fulltxt/RUG01/001/789/916/RUG01-001789916_2012_0001_AC.pdf.

Zeeuw, H.D., R. van Veenhuizen and M. Dubbeling. 2011. "Foresight Project on Global Food and Farming Futures: The Role of Urban Agricultrue in Building Resilient Cities in Developing Countries." Journal of Agricultural Science. 149:153-163. 